\section{P. Karthikeyan \\ Assistant Professor Madras Institute of Technology Anna University Department of Production Technology India}

\section{D.V. Sabarianand}

Research Schola Madras Institute of Technology Anna University

Department of Production Technology India

S. Suganthan
Master Student
Madras Institute of Technology
Anna University
Department of Production Technology
India

\section{Suganthan}

aster Student Anna University India

\title{
Investigation on Adaptability of Carbon Fiber Tube for Serial Manipulator
}

This work describes the investigation on adapting the carbon fiber tube for building lightweight serial manipulator links. The carbon fiber is chosen based on its significant properties such as lightweight and superior mechanical strength, as an alternative to the existing conventional alloys such as steel and aluminium. A serial manipulator also suffers from a few disadvantages. A typical serial manipulator generally has a structure weight to payload ratio of approximately 200:1, which in turn drastically increases the power and torque requirements of the link actuators. So, there is a need to address this serious problem by investigating the lightweight construction for robot arm links through alternative designs. Such a design will significantly decrease the power requirements of the robot arm without compromising on stability. A comparative study has been done considering three different materials: steel, aluminium and carbon fiber using finite element analysis to check payload capability and stress concentrations.

Keywords: FE Analysis, Serial manipulators, CAD modelling, Carbon fiber, Modular joints, Lightweight robot

\section{INTRODUCTION}

Serial manipulators are the most common industrial robots which consist of a series of links connected by motor actuated joints. The main advantage of a serial manipulator is a large workspace with respect to the size of the robot and the floor space it occupies. However, the overall weight to payload of a conventional serial manipulator is approximately 200:1, which leads to the large weight of the overall structure for a given payload. It also drastically increases the power consumption and torque requirements of the link actuators. Hence, it becomes necessary to explore the lightweight serial manipulator links. Industrial robot arm manipulators are predominantly constructed from steel or aluminium for the purpose of stability and to handle large payload. This leads to an increase in overall weight and inertia of moving links. Lightweight robots have been studied before by using alternative materials such as magnesium and FRP but there are a very limited number of studies on the usage of advanced materials such as carbon fibers.

The objective of this work is to identify an appropriate material for lightweight serial manipulators. To achieve the desired objective the following efforts have been carried out. A comparative study has been carried out between three materials such as steel, aluminium and carbon fibers. A static structural analysis of the robot arm using Finite Element (FE) was done. The deformation, stresses and strain developed in the structure were studied. The robot configuration adopted and the 3D model has been presented with special emphasis on the

Received: August 2018, Accepted: December 2018

Correspondence to: P Karthikeyan

Department of Production Technology,

Madras Institute of Technology, Chennai, India

pkarthikeyan@mitindia.edu

doi: $10.5937 /$ fmet1903412K

(C) Faculty of Mechanical Engineering, Belgrade. Allrights reserved joint design. The steps followed within the simulation software to analyze the designed model. Geometry, Meshing and Boundary conditions have been discussed. The results and discussions of the stress, strain and deformation plots are presented, followed by a conclusion.

\section{CURRENT STATUS OF WORK}

Multiple literatures relevant to this topic was extensively studied. Key findings and challenges were adopted as a baseline to proceed this work in an effective manner. Previous works related to lightweight robots and usage of carbon based composites was given emphasis. The author described the DLR MIRO, a compact, slim and lightweight robot of $10 \mathrm{~kg}$ used for surgical applications and to assist the surgeon directly at the operating table without interference. The designed robot arm was able to carry a payload of $30 \mathrm{~N}$ after optimization of kinematics [1]. The authors point out that industrial robots are targeted on high-absolute accuracy which is achieved by stiff structures and thus relatively high mass.

In this paper found the optimum section in which the stress in the members not exceeds the allowable stress and estimated the best choices of the dimension for each section that gives the minimum weight and deflection. The dynamic behavior of the best chosen structure of industrial robot was studied to find the natural frequencies and mode shapes [2].

The author designed, manufactured, characterized and tested a bent tubular carbon/epoxy fiber tube with variable section used as a bicycle handlebar. Tests and analytical computations, based on classical laminated plate theory delivered the engineering constants that have been used in the finite element simulations of two important safety tests for the handlebar (bending and torsion) [3]. 
The author designed a novel prototype lightweight arm based on modular joints, modular connection and light shaft structures. The reason for development was due to the limitations in conventional manipulators. It also discusses the general requirements for lightweight robots, upon which this robot was designed [4]. Modular joints were designed to reduce the robot mass, improve the payload-weight ratio and improve the mechanical bandwidth. With the modular Joints, a sixDOF lightweight robot was designed studied different prototype designs and examined the feasibility of the application of light alloys for robot arm, in comparison to conventional materials [5].

The author investigated CFRP and aluminium robot arms based on structural stiffness (flexural/bending and torsional), tube thickness and material weights. The investigation was performed based on simulations using analytical stiffness models for CFRP and aluminium tubes. The static and dynamic characteristics of the initial aluminium alloy robot arm as well as weight saving considerably improved by using advanced composite material. The optimized CFRP link had much higher stiffness in comparison with the optimized aluminium. Also, the carbon fiber reinforced plastic gave better dynamic performance in comparison with conventional materials, such as aluminium and steel [6].

The author described a vibration analysis of frequencies of robot. The different modes of frequencies for the robot having crack and without having crack based were analyzed on the finite element analysis (FE). A finite element model of the robot was established by utilizing the software of ANSYS Workbench and the model was designed in CATIA V5 with crack and without crack and the frequencies at three different modes are obtained. Finally, the weak parts of the robot arm were found out and improved in the optimized design [7-9].

The author designed robot arm assembly models using two types of cross-sections i.e. square-square, cylinder-cylinder and light weight alloys were assigned to the best performed cross-section type. Magnesium, aluminum and zinc were used as alternate materials for steel. Results of the analysis showed that square-square geometry was superior to cylinder-cylinder geometry and magnesium alloy displayed higher stress values with respect to the weight than that of steel. Finally, it was concluded that square-square cross section was the most suitable in designing of packing robots and Magnesium alloy was most suitable material in manufacturing of packing robots [10].

In this paper investigated a lightweight carbon composite manipulator which uses an I-beam steel manipulator design transferred to a braided design with hollow cross sections and locally adapted material properties. This includes analytical as well as detailed finite element method design. A mechanical testing program was performed in order to measure input-values for the numerical calculations and validate the simulation on system level. Static and dynamic tests of the CFRPmanipulator showed that it fulfils all their basic requirements. The braided CFRP-manipulator was $70 \%$ lighter than the steel and increased handling properties because of locally adapted material properties [11].
Based on the literature survey, a completely new design has been proposed. This design is based on a modular approach as previously suggested by some of the previous works. The modular design will allow for minimal fastening and hence very easy to assemble and disassemble. Also, the design is approached in such a way that a comparative study can be made. For comparison, three different materials have been used: steel, aluminium and carbon fiber.

\section{METHODOLOGY}

From the concept to the final design, multiple design revisions and optimizations have been carried out. The design revisions have been made considering the structural stability of the robot arm. Later, the design was imported within the simulation software, ANSYS workbench to perform the static structural analysis.

A detailed flowchart of the static structural analysis has also been presented in Figure: 1. The robot configuration used in this robot has been discussed. A special discussion has been included on the design of joints. After obtaining the results and determining the optimal dimensions, assembly drawings were prepared as shown in figure. The designed robot arm is a 3 Degree of freedom TRR configuration type otherwise called as Articulated Robot Arm.

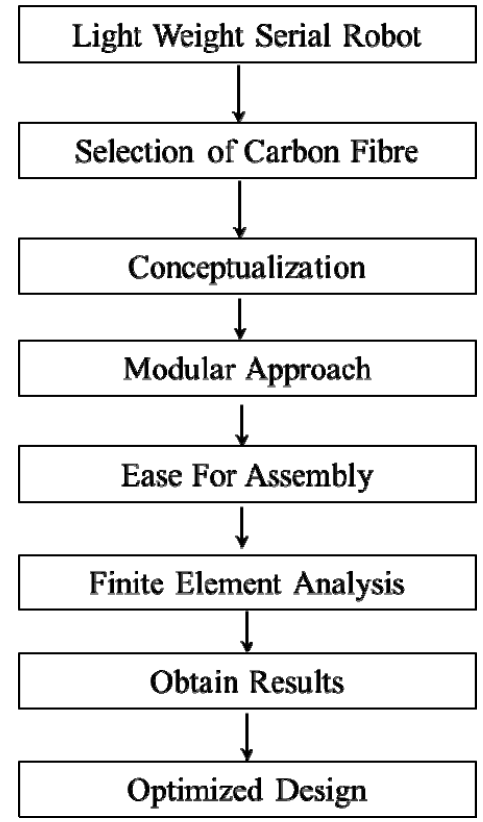

Figure 1: Methodology

\section{DESIGN INSPIRATION}

On reviewing a number of published research papers, it became evident that a number of lightweight robots have already been designed before and also it was understood that the design of the links and joints have been much similar to the design used by the conventional materials. In contrast to the existing trend, a completely new design which has not been tested before has been proposed and investigated. The robot arm was designed in such a way that it would require as minimum manufacturing as possible, such as Machining [12]. In line to that, it was decided to implement the 
Carbon fiber in the form of tubes which are easily available in the market in a variety of sizes. So, to fit this requirement, this particular design has been primarily inspired by the construction of a conventional engineering mini drafter (drafting machine) used for manual drafting.

The engineering mini drafter consists of thin dual metal links in between the two joints. Since this design is inspired by an existing proven design, it is expected that the hollow and lightweight design will allow for wide reach, flexibility and stability. The design has been modified and improved to allow for better fastening of components. The design was created keeping in mind its main requirement i.e. to handle very light loads. A typical example may be similar to that of carrying a measuring probe which weighs in the order of few grams or generally less than a kilogram [13].

\subsection{Design of Joints}

The aim was to create a simple yet robust joint that should also allow for easy assembly and disassembly. Modular approach has been followed between the links and joints where the components are designed to snap fit into its position. Although, an additional fastening may be added for the tubes for extra support. It is to be noted that this joint design has been simplified to a large extent for the purpose of easier FE simulation. The dashed lines in Figure show how the tubes will snap into its position within the joints. The end effector has a protruding rectangular profile for easy application of force for the easy simulation [14].

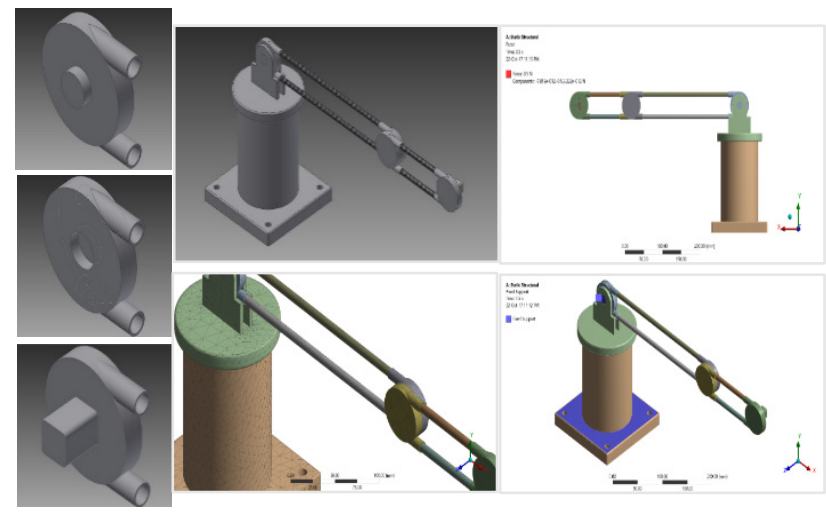

Figure 2:CAD Modelling for FE Analysis

\subsection{FE Analysis}

After the design of the robot arm, the 3D model was exported as a STEP file for performing simulations. All the simulations were carried out using ANSYS ver.18. The primary aim was to simulate and find the payload capability in static condition, of the three different variants. To analyze the payload, a static structural analysis was performed. Load was applied on a configuration in which the robot arm was completely stretched out with all the joints making $0^{\circ}$ or $180^{\circ}$ with respect to each other. The different steps within FE Analysis such as Geometry, Meshing, Loading and Boundary conditions are shown in Figure: 2, along with the joint design [15].

\subsection{Geometry}

In the geometry tab of Static Structural, the geometry was imported as a STEP file. The 3D model was opened within the design modeler within the ANSYS software. The geometry was checked for errors and model cleanup was done.

\subsection{Boundary Conditions}

The boundary conditions are defined, as such, fixed supports and direction of force applications are specified. The serial manipulator is fixed at the base and at the first joint.

\section{MESHING}

In this stage of pre-processing, the entire volume of the object to be analyzed is divided into discrete cells. To obtain the best possible result, the relevance center was chosen as "fine" from the available options: Coarse, Medium, fine. The fine meshing results in a large number of cells. Due to the simplicity of design itself, the mesh was left untouched at its default settings. The system defined meshing contained both tetrahedron and hexahedron mesh.

\subsection{Solver}

After this stage, pre-processing would have been completed. It is to be ensured that all the boundary conditions are clearly defined. The parts are assigned the required material from the database or user-input. Now, the FE model is ready to be solved. Material properties were obtained directly from the ANSYS database. The type of Carbon fiber considered for the simulation was $3 \mathrm{~K}$ type plain weave tubular type, $8 \times 6$ $\mathrm{mm}$ diameter tube.

\section{RESULTS AND DISCUSSIONS}

A major part of this phase of the project was to design the robot arm. At the initial stages of the conceptualization of the design, simulations were carried out. The results of that particular design, showed large unacceptable deformation. So, on further trial and error optimization, the design has been optimized and revised to reduce the value of key parameters to a great extent.

\subsection{Discussions}

For a maximum applied force of $110 \mathrm{~N}$, the equivalent stress values were 269.25 $\mathrm{MPa}$ and 292.14 $\mathrm{MPa}$ for steel and aluminium tube configuration respectively. It is to be noted that both the values are slightly above the yield strength of the respective materials $(250 \mathrm{MPa}$ and $280 \mathrm{MPa}$ ). The increase in stress value is obvious for the aluminium because of its lighter weight compared to steel. The maximum load carried in both the cases was around $100 \mathrm{~N}$.

In Fig $3 \mathrm{a}$ and $3 \mathrm{~b}$ shows the equivalent stress, strain and total deformation of aluminium and steel confi- 
gurations. The total deformation values of aluminium and steel configurations are $8.7337 \mathrm{~mm}$ and $3.4026 \mathrm{~mm}$. The deformation value of steel is low compare to the aluminium because of its material properties.
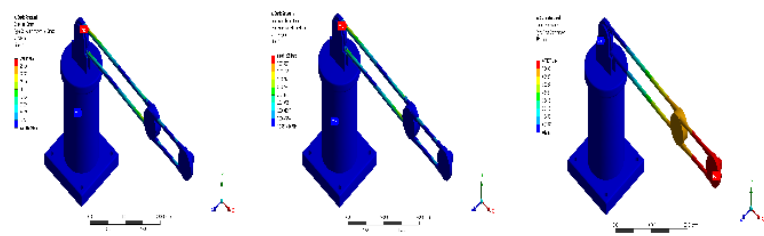

Figure 3a: Equivalent Stress, Strain and Total Deformation of Steel Configuration
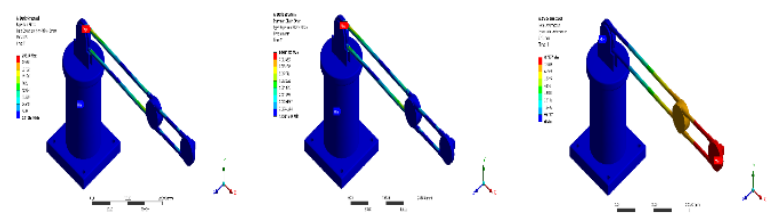

Figure 3b: Equivalent Stress, Strain and Total Deformation of Aluminium Configuration

The Table 1 describes the different types of carbon material in nine different cases in terms of length of the links, orientation and number of carbon fiber layers. Figure $4 \mathrm{a}$ to $4 \mathrm{c}$ describes the equivalent stress, strain and total deformation of $3 \mathrm{k}$ plain weave carbon fiber. TheFig $4 \mathrm{~d}$ to $4 \mathrm{f}$ describes the equivalent stress, strain and total deformation of Twill $2 \times 2$ weave carbon fiber. TheFig $4 \mathrm{~g}$ to $4 \mathrm{i}$ describes the equivalent stress, strain and total deformation of Twill $4 \times 4$ weave carbon fiber.

Table 1. Different Types of Carbon Fiber Material

\begin{tabular}{|c|c|c|c|c|c|}
\hline 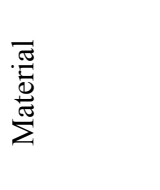 & 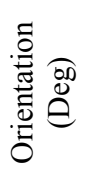 & 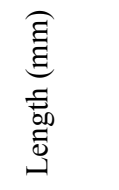 & 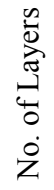 & 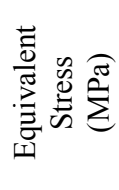 & 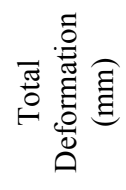 \\
\hline $\begin{array}{l}\text { 3k Plain } \\
\text { Weave }\end{array}$ & 0 & 150,300 & 3 & 305.86 & 7.1016 \\
\hline $\begin{array}{l}\text { 3k Plain } \\
\text { Weave }\end{array}$ & 45 & 140,240 & 4 & 351.53 & 13.4230 \\
\hline $\begin{array}{l}\text { 3k Plain } \\
\text { Weave }\end{array}$ & 90 & 120,220 & 6 & 334.20 & 10.3140 \\
\hline $\begin{array}{c}\text { Twill } 2 \times 2 \\
\text { Weave }\end{array}$ & 0 & 140,240 & 6 & 343.79 & 9.9670 \\
\hline $\begin{array}{c}\text { Twill } 2 \times 2 \\
\text { Weave }\end{array}$ & 45 & 120,220 & 4 & 371.47 & 7.6095 \\
\hline $\begin{array}{c}\text { Twill } 2 \times 2 \\
\text { Weave }\end{array}$ & 90 & 150,300 & 3 & 320.59 & 4.4939 \\
\hline $\begin{array}{c}\text { Twill } 4 \text { x } 4 \\
\text { Weave }\end{array}$ & 0 & 120,220 & 4 & 290.15 & 17.4600 \\
\hline $\begin{array}{c}\text { Twill } 4 \text { x } 4 \\
\text { Weave }\end{array}$ & 45 & 150,300 & 3 & 298.36 & 8.2708 \\
\hline $\begin{array}{c}\text { Twill } 4 \text { x } 4 \\
\text { Weave }\end{array}$ & 90 & 140,240 & 6 & 290.27 & 17.4640 \\
\hline
\end{tabular}

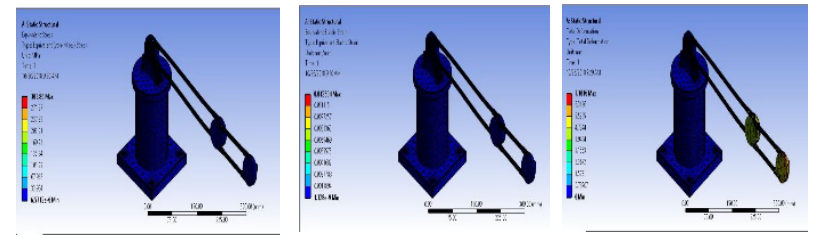

Figure 4a: Equivalent Stress, Strain and Total Deformation of 3K Plain Weave Carbon Fiber
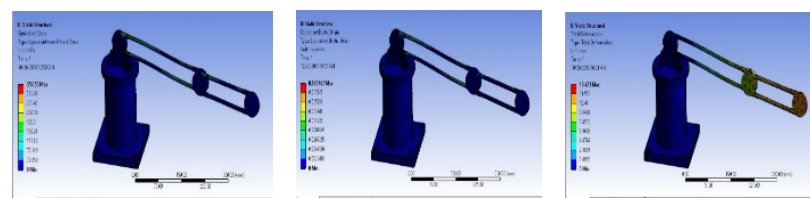

Figure 4b: Equivalent Stress, Strain and Total Deformation of 3K Plain Weave Carbon Fiber
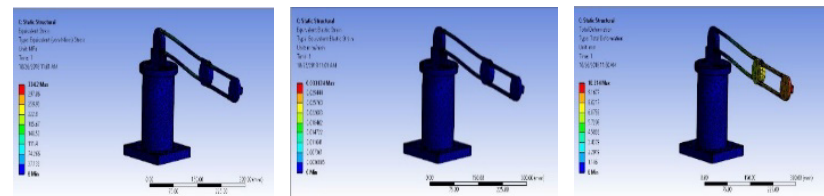

Figure 4c: Equivalent Stress, Strain and Total Deformation of $3 \mathrm{~K}$ Plain Weave Carbon Fiber

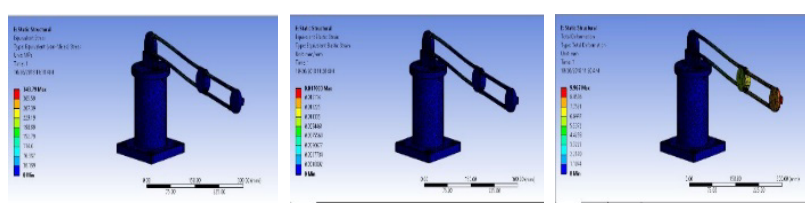

Figure 4d: Equivalent Stress, Strain and Total Deformation of Twill $2 \times 2$ Weave Carbon Fiber
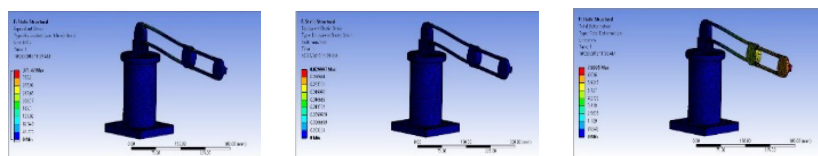

Figure 4e: Equivalent Stress, Strain and Total Deformation of Twill $2 \times 2$ Weave Carbon Fiber
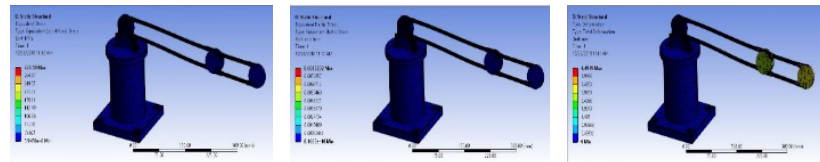

Figure 4f: Equivalent Stress, Strain and Total Deformation of Twill $2 \times 2$ Weave Carbon Fiber
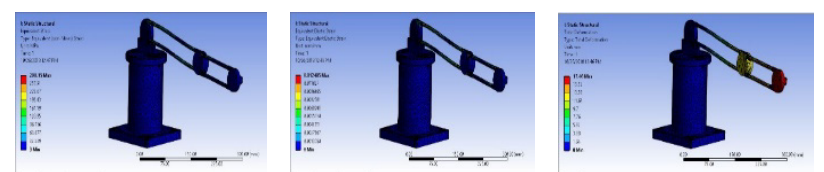

Figure 4g: Equivalent Stress, Strain and Total Deformation of Twill 4 x 4 Weave Carbon Fiber
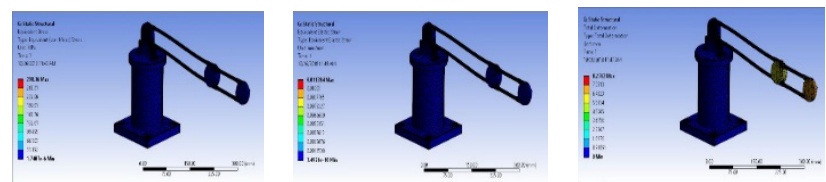

Figure 4h: Equivalent Stress, Strain and Total Deformation of Twill $4 \times 4$ Weave Carbon Fiber
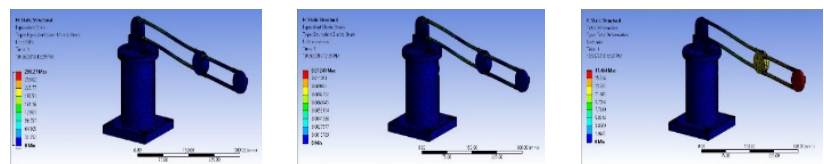

Figure 4i: Equivalent Stress, Strain and Total Deformation of Twill $4 \times 4$ Weave Carbon Fiber

The large increase in deformation is attributed to the drastic weight reduction from steel to aluminium to carbon fiber configuration. Although, it was noted that for a given same load, the carbon fiber construction exhibited lesser deformation [16]. I It is to be noted that the simulations are just an indication of the developed stress values and does not render the point where the 
material fractures. In a static (structural) analysis, it is the decision of the user to find out whether the obtained values from the simulation are acceptable and safe.

\section{DESIGN OPTIMIZATION}

In order find the optimized design from the nine dif-ferent cases of carbon fiber material grey systems opti-mization terchinques is used. The maximum equi-valent stress and total deformation values are taken in the account and compare the values with the steel and alu-minium configurations. A system containing known values and uncertain unknown values is called a grey system, and its mathematical model contains known quantities and uncertain unknown ones (termed grey quantities). An optimization analysis of such a grey system is, conceptually, a problem in which both the objective function and constraint condition include grey quantities $[17,18]$. From the optimized values shown in table 2 results that the Twill $4 \times 4$ Carbon fibre combinations gives the optimal values compare to the other different combination of carbon fibres. While comparing the maximum equivalent stress and total deformation values of Twill $4 \mathrm{x}$ 4 Carbon fibres with steel and aluminium configurations gives the optimal values.

Table 2 Grey Optimization Values

\begin{tabular}{|c|c|c|c|c|c|c|c|c|}
\hline 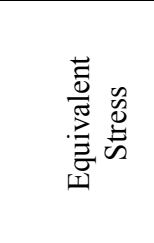 & 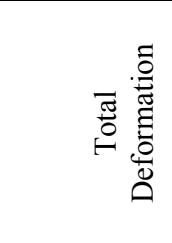 & 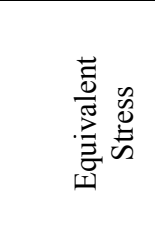 & 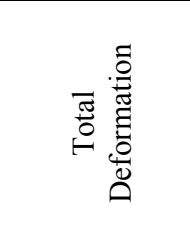 & 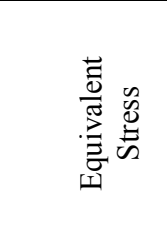 & & 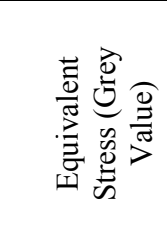 & 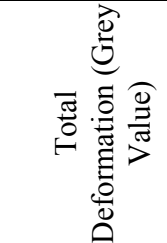 & 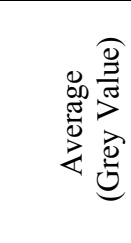 \\
\hline- & - & & & & & & & \\
\hline $\begin{array}{c}49.710454 \\
-\end{array}$ & $\begin{array}{c}17.0271241 \\
-\end{array}$ & 0.2133987 & 0.337109336 & 0.78660127 & 0.662890664 & 0.27609024 & 0.31156185 & 0.293826 \\
\hline $\begin{array}{c}50.919248 \\
-\end{array}$ & $\begin{array}{c}22.5569918 \\
-\end{array}$ & 0.7766766 & 0.806123506 & 0.22332345 & 0.193876494 & 0.57325924 & 0.60743932 & 0.590349 \\
\hline $\begin{array}{c}50.480129 \\
-\end{array}$ & $\begin{array}{c}20.2685425 \\
-\end{array}$ & 0.5720545 & 0.612029326 & 0.42794552 & 0.387970674 & 0.41211875 & 0.4360651 & 0.424092 \\
\hline $\begin{array}{c}50.725865 \\
-\end{array}$ & $\begin{array}{c}19.9712892 \\
-\end{array}$ & 0.6865633 & 0.586817864 & 0.31343672 & 0.413182136 & 0.489048 & 0.42064991 & 0.454849 \\
\hline $\begin{array}{c}51.398475 \\
-\end{array}$ & $\begin{array}{c}17.6271224 \\
-\end{array}$ & 1 & 0.387998022 & 0 & 0.612001978 & 1 & 0.32894665 & 0.664473 \\
\hline $\begin{array}{c}50.118999 \\
-\end{array}$ & $\begin{array}{c}13.0524681 \\
-\end{array}$ & 0.4037742 & 0 & 0.5962258 & 1 & 0.33473707 & 0.23076923 & 0.282753 \\
\hline $\begin{array}{c}49.252451 \\
-\end{array}$ & $\begin{array}{c}24.8408848 \\
-\end{array}$ & 0 & 0.999831247 & 1 & 0.000168753 & 0.23076923 & 0.99943781 & 0.615104 \\
\hline $\begin{array}{c}49.494812 \\
-\end{array}$ & $\begin{array}{c}18.3509504 \\
-\end{array}$ & 0.1129133 & 0.449389286 & 0.88708669 & 0.550610714 & 0.25271954 & 0.35268777 & 0.302704 \\
\hline 49.256043 & 24.8428745 & 0.001651 & 1 & 0.99834899 & 0 & 0.23106268 & 1 & 0.615531 \\
\hline
\end{tabular}

\section{CONCLUSIONS}

A lightweight serial manipulator robot arm design has been proposed using a carbon fiber based construction. A modular design approach has been followed. The dimensions of the various links and joints have been arrived after extensive FEA work. A comparative study has been made using three different materials, i.e. Steel, Aluminium and Carbon fiber composite with nine different cases in terms of length of the links, orientation and number of layers. To find the optimal values from the nine different cases grey system optimization were used. The 3D model of the robot has been simulated using a FEA software to know its structural stability. As a preliminary work, a static structural analysis has been performed. The payload capabilities of the different configurations has been analyzed. The FEA work carried out has yielded satisfactory results and show that the design is good for carrying out further studies.

\section{REFERENCES}

[1] U. Hagn et al., "The DLR MIRO: A versatile lightweight robot for surgical applications," Ind. Rob., vol. 35, no. 4, pp. 324-336, 2008.
[2] D. O. Ramadhan, "Comparative Analysis for Link Corss-Section of Manipulator Arms," vol. 16, no. 2, 2010.

[3] P. Bere, M. C. Dudescu, N. Balc, P. Berce, A. M. Iurian, and O. Nemes, "Design and analysis of carbon/epoxy composite bicycle handlebar," Mater. Plast., vol. 51, no. 2, pp. 145-149, 2014.

[4] S. Bai, M. Ceccarelli, "A Light Weight Arm Designed with Modular Joints," Mech. Mach. Sci., vol. 33, 2015.

[5] H. Liu, H. Huang, "Design and structural analysisof robot arm for high performance packaging robots," vol. 741, pp. 669-674, 2015.

[6] M. Honarpardaz et al. "Benchmark of Advanced Structural Materials for Lightweight Design of Industrial Robots," pp. 3178-3183, 2015.

[7] S. Sahu, B. B. Choudhury, and B. B. Biswal, "A Vibration Analysis of a 6 Axis Industrial Robot Using FEA," Mater. Today Proc., vol. 4, no. 2, pp. 2403-2410, 2017.

[8] D. Djuric, "On brachistochronic motion of a multibody system with two degrees of freedom with real constraints," FME Trans., vol. 43, no. 2, pp. 173178, 2015. 
[9] P. B. Petrovic and N. A. Lukic, "Configurationbased compliance control of kinematically redundant robot arm Part I - theoretical framework," FME Trans., vol. 45, no. 4, pp. 468-474, 2017.

[10] V. U. Sai, V. Prasad, "Geometric parameters optimization \& Analysis of packing robot arm using ANSYS," vol. 3, no. 30, pp. 1-6, 2017.

[11] P. Middendorf, P. Böhler, F. Gnädinger, F. Heieck, and K. Birkefeld, "8 . 3 Design Study for a Carbon Composite Manipulator,” vol. 8, pp. 47-60, 2018.

[12] M. Ayyıldız and K. Çetinkaya, "Comparison of four different heuristic optimization algorithms for the inverse kinematics solution of a real 4-DOF serial robot manipulator," Neural Comput. Appl., vol. 27, no. 4, pp. 825-836, 2016.

[13] J. Pinskier, B. Shirinzadeh, L. Clark, and Y. Qin, "Development of a 4-DOF haptic micromanipulator utilizing a hybrid parallel-serial flexure mechanism," Mechatronics, vol. 50, no. January, pp. 5568, 2018.

[14]X. Shunli, L. Yangmin, and Z. Xinhua, "Design and analysis of a novel flexure-based XY micropositioning stage driven by electromagnetic actuators," Fluid Power Mechatronics (FPM), 2011 Int. Conf., no. X, pp. 953-958, 2011.

[15] K. Cai, Y. Tian, F. Wang, D. Zhang, and B. Shirinzadeh, "Development of a piezo-driven 3DOF stage with T-shape flexible hinge mechanism," Robot. Comput. Integr. Manuf., vol. 37, pp. 125-138, 2016.

[16] R. Dong, Y. Tan, and Y. Xie, "Identification of micropositioning stage with piezoelectric actuators," Mech. Syst. Signal Process., vol. 75, pp. 618-630, 2015.
[17] Y. Zheng and R. W. Lewis, "On the optmization concept of grey systems," Appl. Math. Model., vol. 17, no. 7, pp. 388-392, 1993.

[18]X. Shen and Z. Lu, "The Application of Grey Theory Model in the Predication of Jiangsu Province's Electric Power Demand," AASRI Procedia, vol. 7, pp. 81-87, 2014.

\section{ИСТРАЖИВАЫЕ ПРИЛАГОДЉИВОСТИ ЦЕВИ ОД УГЉЕНИЧНИХ ВЛАКАНА КОД СЕРИЈСКОГ МАНИПУЛАТОРА}

\section{П. Картикејан, Д.В. Сабариананд, С. Сугантан}

Рад се бави истраживањем могућности прилагођавања цеви од угљеничних влакана за израду зглобова мале тежине код серијског манипулатора. Угљенична влакна су изабрана због мале тежине и механичке чврстоће као алтернатива постојећим конвенционалним легурама као што су челик и алуминијум. Серијски манипулатор има и неколико недостатака: однос тежине и корисног оптерећења је приближно 200:1, што захтева знатно већу снагу и обртни момент код зглобова актуатора. Овај озбиљан проблем је истражен са аспекта лаке конструкције за зглобове роботске руке кроз алтернативни дизајн. Такав дизајн ће значајно смањити потребе роботске руке за снагом при чему стабилност неће бити угрожена. Извршено је компаративно проучавање три различита материјала: челика, алуминијума и угљеничних влакана применом анализе коначних елемената у циљу провере капацитета корисног оптерећења и концентрације напона. 